\title{
In vitro morphogenic response from zygotic embryos of Genipa americana
}

\author{
Annie Carolina Araújo de Oliveira ${ }^{*}$ Caroline de Araújo Machado ${ }^{1}$ \\ Leila Albuquerque Resende de Oliveira ${ }^{1}$ Ana Veruska Cruz da Silva ${ }^{2}$ Ana da Silva Lédo ${ }^{2}$
}

${ }^{1}$ Programa de Pós-graduação em Agricultura e Biodiversidade (PPGAGRI), Universidade Federal de Sergipe (UFS), Av. Marechal Rondon s/n, Jardim Rosa Elze, 49100-000, São Cristóvão. SE, Brasil. E-mail: anniedeoliveira@hotmail.com. *Corresponding author.

${ }^{2}$ Empresa Brasileira de Pesquisa Agropecuária (Embrapa Tabuleiros Costeiros), Aracaju, SE, Brasil.

\begin{abstract}
The aim of this study was to evaluate the in vitro morphogenic potential of genipap (Genipa americana L.) zygotic embryos. Seeds obtained from ripe fruits had their zygotic embryos excised and inoculated in MS medium with 4.44 $\mu M$ of 6-benzylaminopurine (BAP) and supplemented with 0.0; 1.07; 2.14 and 3.21 $\mu \mathrm{M}$ of naphthalene acetic acid (NAA). The potential of explants regeneration and the shoot length and number of leaves in plantlets were evaluated. The in vitro regeneration of genipap is possible from the conversion of zygotic embryos in a MS medium with $4.44 \mu \mathrm{M}$ BAP supplemented with $3.21 \mu M N A A$.

Key words: plant tissue culture, plant growth regulators, callus.
\end{abstract}

Resposta morfogênica in vitro de embriões zigóticos de Genipa americana

RESUMO: O objetivo do trabalho foi avaliar o potencial morfogênico in vitro de embriões zigóticos de jenipapeiro (Genipa americana L.).

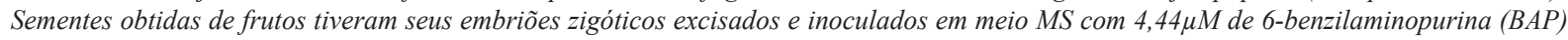
suplementado com 0,0; 1,07; 2,14 e 3,21 $\mu \mathrm{M}$ de ácido naftaleno acético (ANA). O potencial de regeneração dos explantes e o comprimento da parte aérea e o número de folhas nas plântulas formadas foi avaliado. Observou-se que é possivel a regeneração in vitro de jenipapeiro a

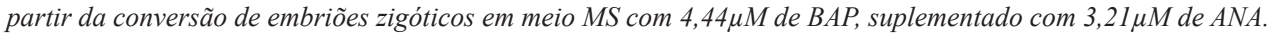

Palavras-chave: cultura de tecidos vegetais, reguladores de crescimento vegetal, calos.

Genipa americana L. (Rubiaceae), popularly known as genipap has an economic importance, both for its forestry and environmental potential (DURÃES et al., 2014). Predominantly exploited in an extractive way, this species has undergone accelerated genetic erosion. Conventional propagation occurs through seeds, but it is restricted due to non-uniformity of germination and rapidly loss of seed viability, since they are classified as intermediate (MAGISTRALI et al., 2013).

Application of tissue culture techniques works as a tool to overcome propagation problems of species such as genipap. These techniques use not only enables the maximization of production of seedlings with genetic fidelity, but also ensures the conservation of germplasm (REED et al., 2011). However, in vitro propagation is only possible when considering the regenerative potential that each genotype has, giving the morphogenic responses that different types of explants, medium composition and culture conditions may present (ELHITI \& STASOLLA, 2011). As general rule, younger tissues have higher cell competence. Therefore, the cultivation of zygotic embryos has been used for the observation of processes which control in vitro morphogenesis (HU \& FERREIRA, 1998). The aim of this study was to evaluate the effect of morphogenic potential of genipap zygotic embryos submitted to different concentrations of NAA in the presence of BAP.

Ripe fruits were collected from natural populations of Nucleo Bandeirante, Distrito Federal, Brazil. Extracted seeds were kept at room temperature for 24 hours, and disinfected under laminar flow chamber by immersion in $70 \%$ alcohol for $1 \mathrm{~min}$, followed by $2.5 \%$ 
(v/v) solution of sodium hypochlorite plus Tween-20 ${ }^{\circledR}$ for 20min and three times washed in distilled water. After that, the zygotic embryos were excised and inoculated in test tubes containing 20mL MS (MURASHIGE \& SKOOG, 1962) medium with $30 \mathrm{~g} \mathrm{~L}^{-1}$ sucrose, $4 \mathrm{~g} \mathrm{~L}^{-1}$ de Phytagel $^{\circledR}, 4.44 \mu \mathrm{M}$ of BAP and supplemented with 0.0 ; $1.07 ; 2.14$ and $3.21 \mu \mathrm{M}$ of NAA. The $\mathrm{pH}$ of the culture medium was adjusted to 5.8 , and autoclaved at $120 \pm 1^{\circ} \mathrm{C}$ for $20 \mathrm{~min}$. Cultures were kept in darkness for 15 days, and then transferred to a growth room, where they remained for 45 days at $25 \pm 2^{\circ} \mathrm{C}$, under a photoperiod of $16 / 8$ hours.

The experimental design was completely randomized with four treatments, and which treatment composed by twenty replications with one explant per tube. After 30 days, regeneration (\%) was evaluated. Shoot length and number of leaves were scored in plantlets regenerated at 60 days. For the effect of NAA concentration, regression equations were estimated, using the SISVAR statistical software (FERREIRA, 2011).

Regeneration percentage showed a positive linear behavior (Figure 1A). In the absence of NAA, regeneration percentage was $40 \%$ with increase up to $70 \%$ in response of the presence of this regulator. The combination between $4.44 \mu \mathrm{M}$ BAP and NAA may promote an initial stimulus for the development of embryos. Similar results were reported by LÉDO et al. (2002) and LEITE et al. (2014) in cultivations with Euterpe oleracea Mart. and Orbignya oleifera Burret, respectively. Also, cytokinins are known for regulate several cellular processes, including the expansion of cotyledons into dicotyledons (TAIZ \& ZEIGER, 2013). Cotyledons act as nutritional reserves which will maintain the embryo until its development into plantlet, which becomes autotrophic (LÉDO et al., 2008).

Shoot length presented positive quadratic behavior in the presence of NAA(Figure 1B). Reduction in shoot length was observed with the increase of NAA concentration, resulting in higher growth $(30.83 \mathrm{~mm})$ in the absence of this phytohormone. Auxins are important for maintenance the apical dominance and higher endogenous concentrations may result in inhibition of shoot emission (TAIZ \& ZEIGER, 2013). This result agrees with REZENDE et al. (2011), who reported higher shoot growth $(24.40 \mathrm{~mm})$ in Coffea arabica L. somatic embryos in the absence of plant growth regulators. The same positive quadratic behavior was observed for number of leaves with minimum point of $3.16 \mu \mathrm{M}$ NAA (Figure 1C). Increasing NAA concentration promoted a reduction in the number of leaves. Otherwise, rooting was observed in $10 \%$ of plantlets in MS medium with all NAA concentrations.

Direct organogenesis was not observed but the progressive increase in concentrations of NAA with
$4.44 \mu \mathrm{M}$ BAP resulted in a considerable number of plantlets with compact callus formation at the explants base. Callus formation is associated with the balance between auxin and cytokinin (TAIZ \& ZEIGER, 2013). In recent studies on genipap, ALMEIDA et al. (2015) have reported callus formation in nodal and leaf segments inoculated in MS medium with 18.10 and $36.20 \mu \mathrm{M} 2,4-\mathrm{D}$ (dichlorophenoxyacetic acid) and in the presence of $7.86 \mu \mathrm{M}$ BAP for leaf explants. Although, it is not the preferred route to plant regeneration, callus formation has been the basis for studies related to somatic embryogenesis and production of in vitro secondary metabolites (NOGUEIRA et al., 2007).

It is possible to obtain in vitro genipap regeneration from the conversion of zygotic embryos on MS medium supplemented with $4.44 \mu \mathrm{M}$

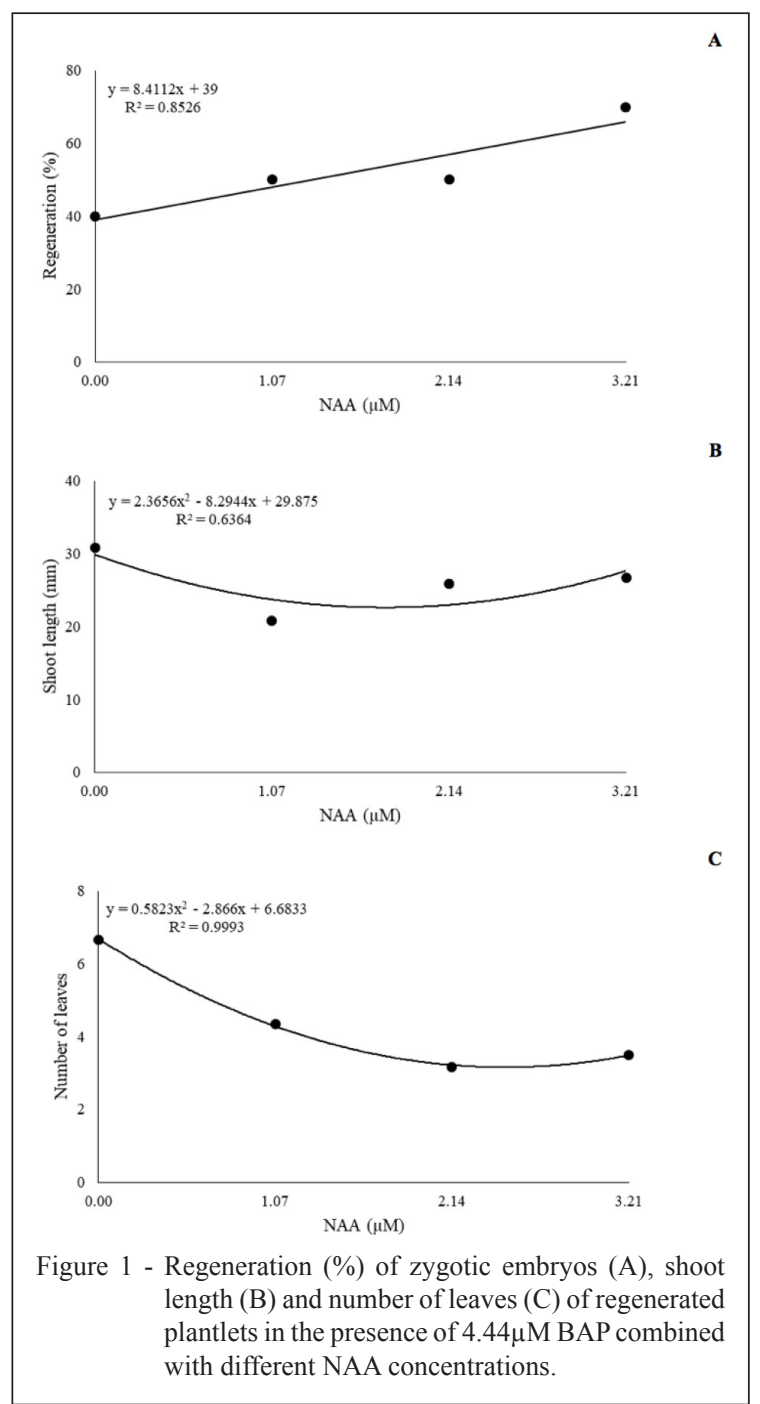


BAP and NAA. In additional, more regenerative response is possible in the presence of $3.21 \mu \mathrm{M}$ NAA. Considering the different responses obtained in this study, further researches should be carried out aiming to improve the morphogenetic expression of genipap zygotic embryos.

\section{ACKNOWLEDGMENTS}

Universidade Federal de Sergipe (PPGAGRI/UFS), Empresa Brasileira de Pesquisa Agropecuária (EMBRAPA), and Conselho Nacional de Desenvolvimento Científico e Tecnológico $(\mathrm{CNPq})$ for financial support and fellowship.

\section{REFERENCES}

ALMEIDA, C.S. et al. Morphogenetic responses of jenipapo in different in vitro culture conditions. Revista Caatinga, v.28, n.1, p.5864, 2015. Available from: <http://periodicos.ufersa.edu.br/revistas/ index.php/sistema/article/view/3069>. Accessed: Sept. 14, 2016.

DURÃES, M.C.O. et al. Floristic survey of arboreal stratum of three fragments of riparian forest as a subsidy to 'Rio Cedro' vegetation recomposition in Montes Claros - MG. Ciência Florestal, v.24, n.1, p.47-58, 2014. Available from: $<$ http://cascavel.ufsm.br/revistas/ojs2.2.2/index.php/cienciaflorestal/article/view/13322>. Accessed: July 14, 2016. doi: 10.5902/1980509813322.

ELHITI, M.; STASOLLA, C. The use of zygotic embryos as explants for in vitro propagation: an overview. In: THORPE, T.A.; YEUNG E.C. Plant embryo culture: methods and protocols. New York: Humana, 2011. Cap.17, p.229-255.

FERREIRA, D.F. SISVAR: a computer statistical analysis system. Ciência e Agrotecnologia, v.35, n.6,p.1039-1042,2011.Available from: $<$ http://www. scielo.br/scielo.php?script=sci_arttext\&pid=S1413-70542011000600001. Accessed: Oct. 04, 2016. doi: 10.1590/S1413-70542011000600001.

HU, C.Y.; FERREIRA, A.G. Cultura de embriões. In: TORRES, A.C. et al. Cultura de tecidos e transformação genética de plantas. Brasília: Embrapa - SPI/Embrapa-CNPH, 1998. p.371-393.

LÉDO, A.S. et al. Germinação in vitro de embriões zigóticos e sementes de nim indiano (Azadirachta indica A. Juss.). Revista Brasileira de Plantas
Medicinais, v.10, n.3, p.1-5, 2008. Available from: <http://www.sbpmed. org.br/download/issn_08 3/artigo1_v10n3.pdf $>$. Accessed: July 22, 2015.

LÉDO, A.S. et al. Somatic embryogenesis from zygotic embryos of Euterpe oleracea Mart. Revista Brasileira de Fruticultura, v.24, n.3, p.601-603, 2002. Available from: <http://www.scielo.br/scielo. php?script $=$ sci arttext\&pid $=\mathrm{S} 0100-29452002000300004>$. Accessed: Sept. 08, 2016. doi: 10.1590/S0100-29452002000300004.

LEITE, M.S. et al. In vitro germination of babassu: influence of growth regulators in zygotic embryos. Acta Scientiarum, v.36, n.4, p.449-456, 2014. Available from: <http://www.scielo.br/ scielo.php?script $=$ sci arttext\&pid $=\mathrm{S} 1807-86212014000400009>$ Accessed: Sept. 10, 2016. doi: 10.4025/actasciagron.v36i4.15484.

MAGISTRALI, P.R. et al. Physiological behavior of Genipa americana L. seeds regarding the capacity for desiccation and storage tolerance. Journal of Seed Science, v.35, n.4, p.495-500, 2013. Available from: $<$ http://www.scielo.br/scielo.php?script=sci arttext \&pid=S2317-15372013000400011>. Accessed: Aug. 12, 2016. doi: $10.1590 / \mathrm{S} 2317-15372013000400011$

MURASHIGE, T.; SKOOG, F. A revised medium for rapid growth and bioassays with tobacco tissue cultures. Physiologia Plantarum, v.15, n.3, p.473-479, 1962. Available from: $<$ http://onlinelibrary.wiley. com/doi/10.1111/j.1399-3054.1962.tb08052.x/abstract>. Accessed: Oct. 24, 2016. doi: 10.1111/j.1399-3054.1962.tb08052.x.

NOGUEIRA, R.C. et al. Calli induction from leaf explants of muricipequeno (Byrsonima intermedia A. Juss.). Ciência e Agrotecnologia, v.31, n.2, p.366-370, 2007. Available from: <http://www.scielo.br/ scielo.php?script $=$ sci_arttext\&pid=S1413-70542007000200015>. Accessed: Sept. 21, 2016. doi: 10.1590/S1413-70542007000200015.

REED, B.M. et al. Biodiversity conservation and conservation biotechnology tools. In vitro Cellular \& Developmental Biology - Plant, v.47, n.1, p.1-4, 2011. Available from: <http://link. springer.com/article/10.1007\%2Fs11627-010-9337-0>. Accessed: Aug. 20, 2016. doi: 10.1007/s11627-010-9337-0.

REZENDE, J.C. et al. Effects of auxins and cytokinins on the development of Coffea arabica L. somatic embryos. Plant Cell Culture \& Micropropagation, v.7, n.1, p.1-8, 2011. Available from: <http:// www.abctp.org.br/revista/v7n1.pdf $>$. Accessed: Aug. 01, 2016.

TAIZ, L.; ZEIGER, E. Fisiologia vegetal. Porto Alegre: Artmed, 2013. 5v. 918 p. 